\title{
Application of Plated Rubber System (PRESS) for Rubber Identification
}

\author{
Razman Hafifi Redzuan ${ }^{1}$, Mohamed Dahlan Ibrahim ${ }^{1}$, Mohd Rosli Mohamad ${ }^{1} \&$ Muhammad Zaly Shah Muhammad \\ Hussein $^{2}$ \\ ${ }^{1}$ Faculty of Entrepreneurship \& Business, Universiti Malaysia Kelantan, Malaysia \\ ${ }^{2}$ Faculty of Built Environment, Universiti Teknologi Malaysia, Malaysia \\ Correspondence: Razman Hafifi Redzuan, Faculty of Entrepreneurship \& Business, Universiti Malaysia Kelantan, \\ Malaysia
}

Received: May 1, 2019

Accepted: June 1, 2019

Online Published: July 7, 2019

doi:10.5430/rwe.v10n2p62

URL: https://doi.org/10.5430/rwe.v10n2p62

\begin{abstract}
Rubber prices are influenced by several factors including supply and demand especially from countries who are major rubber producers and consumers as well the growth rate of the world economy. High rubber prices increase the incidence of rubber theft, thus forcing the owners to build hut and camp in their rubber estates to prevent such occurrence. Rubber theft becomes prevalent not only at night but also in the broad daylight as the commodity price increases. From the survey, it has been noted that more than 10 incidents of theft have been reported within 15 days. Plated Rubber System (PRESS) was developed to imprint an identification entity on rubber that leads to identifying the ownership. With the invention of this system, the stolen number of rubber can be reduced because each rubber smallholders has their personal serial identification plate. The main objective PRESS is to establish an identification of rubber, helping to reduce the theft of rubber at farm level as well as to curb the sale of stolen rubber. In addition, it can be used to regulate the quality of rubber produced by smallholders and developing a database profile of rubber smallholders. The finding shows that the respondent agreed that the innovation of PRESS may help them to reduce the prevalence of rubber theft and increase the good practice of plantation management that leads to greater efficiency and productivity.
\end{abstract}

Keywords: application rubber system, rubber identification

\section{Introduction}

Malaysia is the third largest rubber producer in the world, after Thailand and Indonesia (Heru \& Andus, 2010). Rubber or its scientific name Hevea brasiliensis is one of the first commodity crop planted in large scale in Malaysia, besides cocoa, palm oil and tobacco (Chandrasekhar et al., 2005). Rubber trees are a major producer of natural latex (Wongcharoen, 2011). Besides, latex rubber wood can be used for furniture making and as the main raw material in the production of wood-based panels such as particleboard and medium density fiber board in Asia (Ayrimis et al., 2011), thus rubber is economically important industrial commodity (Prabhakaran, 2010; Kyrychenko, 2018).

Rubber plantation in Malaysia is divided into two main sectors, namely smallholder sector $(\leq 40.48$ ha $)$ and plantation sector ( $\geq 40.48 \mathrm{ha}$ ) (Malaysia Rubber Board, 2006), where mostly are dominated by the smallholder sector for about 95.6\% (Ramli \& Vanaja, 2011; Kubat \& Dedebali 2018). In Kelantan, the area of rubber plantation was increasing since the year 2007. This is due to the increasing of new planting and replanting application by the group of rubber planting scheme advocated by Rubber Industry Smallholders Development Authority (RISDA). The soil and climate suitability in Kelantan as well as promoting the rubber planting has widely become an important factor in the increasing area of rubber plantation in Kelantan (Heru \& Andus, 2010). RISDA is the Malaysian state agency that is responsible for the development of the rubber plantation in the state by giving assistance to the small rubber owners to ensure the efficient implementation of the rubber planting. RISDA is also responsible to develop the rubber industry integrated management to the smallholders' sector efficiently and increase the rubber production commercially as well as diversifying into the downstream activities in order the capacity of competing in global markets (RISDA, 2012; Likitrattanaporn, 2018). The rubber smallholders are encouraged to replant using the new rubber clones that have better quality and disease resistant (Ang \& Faera, 2011). The rubber planting scheme has two-prong objectives; which are to improve the income of smallholders and to use the idle land for the production of rubber wood and wood supply in the future (Malaysia Rubber Board, 2010; Mansor \& Ilias 2013). 
In the current study, the area where Plated Rubber System (PRESS) is piloted was located in Gua Musang Rubber Smallholders Community, north of Kelantan and at Kampung Tok Sangkut, Pasir Mas, Kelantan. PRESS was developed by a team of researchers led by Razman Hafifi Redzuan, whereby the main function of this innovation is to create a unique identification of rubber identity. One of the major problems faced by the smallholders is the theft of rubber, as reported by $74.4 \%$ of the respondent participated in the survey (Kodoh, J et al., 2016; Lari, NYangweso \& Rono 2017). The objective of this research is to explain how PRESS is developed and implemented in the piloted area involving the smallholders with the consent from RISDA. It is envisaged that the system will help to determine the ownership of the solidified latex, and with the integration of data base it will also curb the number of stolen rubber from the plantation.

\section{Material \& Methods}

In first attempt, the development of PRESS was using iron and tin (Figure 1). Tin was attached to the iron using soldering method. The tin already has patterns with certain coding (number and letter). The combination of iron and tin were placed in a rubber container using rivets (Figure 2).

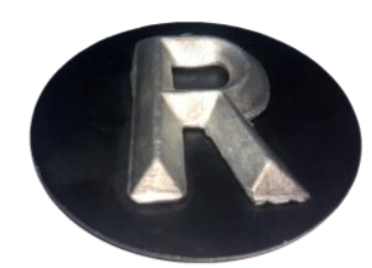

Figure 1. Iron and Tin bonded together

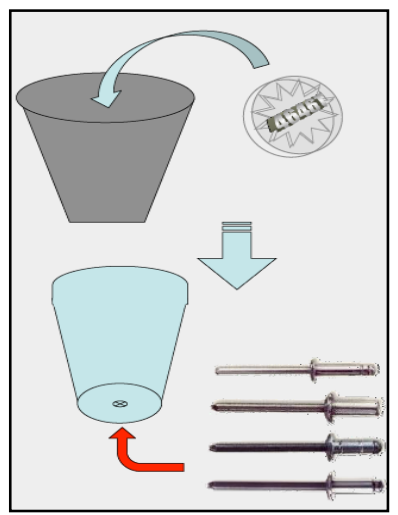

Figure 2. Procedure of PRESS were placed in a rubber container

In the first round of implementation of PRESS using metal and tin, we found that there is a chemical reaction between the latex and the plating. This is because formic acid that was used to catalyze the process to harden the rubber makes the rubber become brownish and blackish (Figure 3), thus reducing the quality of rubber and as a consequence the rubber has to be sold at a lower price.

The researcher made a decision to use a different material to make the plate, which leads to the success of this research. The researcher has chosen the quality of plastics that is similar to the one used to create rubber container. Polypropylene (PP) is then used to create PRESS. PP is strong and can usually withstand higher temperatures. It has been used to make lunch boxes, margarine containers, and yogurt pots. Plastic bottle caps are often made from PP. These new plating apparatus were implemented in RISDA Sungai Galas; Gua Musang Kelantan that involved 200 rubber trees covers of 2 acres; and 100 rubber trees in Kampung Tok Sangkut, Pasir Mas Kelantan own by Agri'Pro Company. The collection of solidified latex was done after the completion of one cycle and that usually takes 2-5 days before harvest. The data were collected at different period and it depends on the maturity of the rubber tree. 


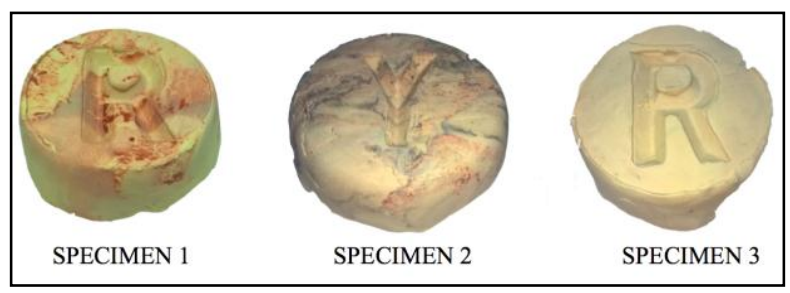

Figure 3. The rubbers become brownish (Specimen 1) and blackish (Specimen 2) cause of chemical reaction. Specimen 3 is normal rubber

The qualitative method also used in this research which involved procedures and techniques in order to enquire feedback from the respondent. The method for coding, organizing and analyzing data were adopted from Kirby and McKenna (1989), and Miles and Huberman (1984). Interviews were conducted with the representative of the company; RISDA and Agri'Pro Co. who had involved physically with the project. The respondents were asked about their plantation experience, their experiences with the implementing of PRESS and without it, their perceptions of what was going well for them and their recommendation towards the instrument. Several themes emerged and were documented. The characteristics of each finding and relationships between them were noted. The finding, the characteristics, the possible interpretations, and recommendations were discussed and confirmed with the participants in focus groups.

\section{Results}

The total number of rubber collected was 1200, comprising $66.7 \%$ at Gua Musang and $33.3 \%$ at Pasir Mas Kelantan. The majority of the rubber shows the clear identification number and letter when the rubber collection is made four times in a sequence. The identification of plate (mold) in recognizable form is $96 \%$ over 800 rubber collection in Gua Musang Kelantan, and for Pasir Mas Kelantan is about $94 \%$ over 400 rubbers, in similar form. The rubber collectors comprising 8 workers agreed $100 \%$ that they can identify their rubber easily.

As the respondent shared their experience over the implementation of PRESS, several significant insights emerged. Inconsistent of latex price; when the price at peak the implementation of PRESS is totally significant, but it becomes less important when the price is low. This is because the number of stolen rubber increased in tandem with the increase of rubber price. PRESS is worth to invest if the estate is significantly bigger; at least 5 acres. The reason is due to the high development cost of the mold where each mold with different identification cost about RM600. From the research, we suggest that the cost could be more manageable if integration of mold is done within the state with the assistance from RISDA.

All respondent agreed that the innovation of PRESS is able to help them to reduce the number of rubber theft and increased the good practice of plantation management that leads to greater efficiency and productivity. It may also develop significant impact to secure and identify the right owner of the rubber, consequently increasing the income of the smallholders.

\section{Conclusion and Discussion}

The basic goal of PRESS is to reduce the number of rubber theft thru a modern dynamic system of molding entire plantation, which in the long term it will generate plotting system that may help future planning of rubber plantation. The successful implementation of PRESS needs the change in the mindset of smallholders, the size of the plantation and policy support springing from current practice. One condition is the cooperation and integration molding system, by the state as suggested above may increase the successful rate of PRESS implementation. Such policy of buying rubber is a State matter in Malaysia and deserves far more attention than the current practice. Another condition is in the aspect of technology upgrading as more information is gathered and would justify the further need for research funding for the integration of information data into a database.

\section{Acknowledgement}

The authors would like to express our deepest appreciation and sincere gratitude to the Agri'Pro Co., Rubber Industry Smallholders Development Authority (RISDA) and all of the smallholder community involved in Gua Musang and Pasir Mas Kelantan for their invaluable assistance and contribution that made this knowledge transfer program possible. 


\section{References}

Ang, C. S., \& Faera, A. R. (2011). Pulangan pelaburan ekonomi kepada pekebun kecil getah. Tanaman getah yang menguntungkan (pp.3-4). Sains \& Tekologi Lembaga Getah Malaysia.

Ayrimis, N., Bauchongkol, P., Fueangvivat, V., \& Jarusombuti, S. (2011). Effect of termal treatment of rubberwood fibers on physical and mechanical properties of medium density fireboard. Journal of Tropical Forest Science, 23(1), 10-16.

Chandrasekhar, T. R., Alice, J., Varghese, Y. A., Saraswathyamma, C. K., \& Vijayakumar, K. R. (2005). Girth growth of rubber (Hevea brasiliensis) trees during the immature phase. Journal of Tropical Forest Science, 17(3), 399-415.

Heru, S., \& Agus, A. (2010). Penanaman Getah (p.160). Synergy Media, Majeed S.A. \& Co. Sdn. Bhd, Kuala Lumpur, Malaysia.

Kirby, S., \& McKenna, K. (1989). Experience, Research, Social Change: Methods from the Margins. Toronto, ON: Garamond Press.

Kodoh, J., Sinusun, V., Liew, K. C., Maid, M., Lintangah, W., \& Mojiol, A. R. The Contributions of Rubber Plantation to the Socio-Economic Development: A Case Study on Kanibongan Project-Rubber Smallholders Community in Pitas, Sabah.

Kubat, U., \& Dedebali, N. C. (2018). Opinions of Science Teachers for Classroom Management. Journal of Education and e-Learning Research, 5(2), 110-117. https://doi.org/10.20448/journal.509.2018.52.110.117

Kyrychenko, V. (2018). Indonesias Higher Education: Context, Policy, and Perspective. Asian Journal of Contemporary Education, 2(2), 159-172. https://doi.org/10.18488/journal.137.2018.22.159.172

Lari, L. R. A., NYangweso, P. M., \& Rono, L. J. (2017). Determinants of Technical Inefficiency of Saccos in Kenya: A Net Operating Cash Flows Output Slack Analysis. Asian Journal of Economics and Empirical Research, 4(2), 49-60. https://doi.org/10.20448/journal.501.2017.42.49.60

Likitrattanaporn, W. (2018). A Study of Language Learning Strategies for Practical Use through the Process of Cooperative Learning. International Journal of Educational Technology and Learning, 3(1), 35-44. https://doi.org/10.20448/2003.31.35.44

Malaysia Rubber Board. (2010). Status penanaman getah tanaman semula dan tanaman baru. unpublished.

Mansor, N. H., \& Ilias, A. (2013). Goods and services tax (GST): A new tax reform in Malaysia. International Journal of Economics Business and Management Studies, 2(1), 12-19.

Miles, M. B., \& Huberman, A. M. (1984). Qualitative Data Analysis: A Sourcebook of New Methods. Beverly Hills, CA: Sage Publications.

Prabhakaran Nair, K. P. (2010). The agronomy and economy of important tree crops of the developing world (p.311). Elsevier Publications, Amsterdam.

Ramli, O., \& Vanaja, V. (2011). Program pengembangan untuk pekebun kecil getah di Malaysia (pp.1-5). Sains dan Teknologi Lembaga Getah Malaysia.

Rubber Industry Smallholders Development Authority RISDA. (2012). Rancangan Tanam Semula: Pekebun Kecil (Smallholder); Section 2, Part 1, Ordinance 8/1952, unpublished.

Wongcharoen, A., Pando, A., Nandris. D., Hanboonsoon, Y., Hartmann, C., \& Rouland-Lefevre, C. (2011). Biological activity of soil under rubber tree (Hevea brasiliensis) affected by trunk phloem necrosis. Forest Phathology, 41(1), 41-47. https://doi.org/10.1111/j.1439-0329.2009.00634.x 